\title{
Effect of brine and dry salting methods on the physicochemical and microbial quality of chub (Squalius cephalus Linnaeus, 1758)
}

\author{
Arzu BINICI ${ }^{1}$, Gülderen Kurt KAYA ${ }^{2 *}$
}

\begin{abstract}
The present study, looks at the physicochemical and microbiological quality changes that occur due to different salting techniques ( $20 \%$ salt concentration) of chub (Squalius cephalus) and when stored in $4 \pm 0.5^{\circ} \mathrm{C}$. Samples of fish from each group was taken on the $15,30,45,60,90$ and $120^{\text {th }}$ day and was analyzed for nutritional component (crude protein, lipid, moisture, crude ash), $\mathrm{pH}$ value, salt content and the microbial flora (total mesophilic aerobic bacteria count, total coliform, total psychrophilic aerobic bacteria count, yeast and mould). It was determined that crude protein, lipid, crude ash and salt amounts in the group where dry salting method was applied were higher than the group where brine salting occurred, in addition protein and lipid values decreased as storage period was longer $(\mathrm{P}<0.05)$. It was determined that there is an increase in total aerobic mesophilic, psycrophile bacteria and enumeration of yeast and mould as storage period increased, while coliform bacteria decreased $(\mathrm{P}<0.05)$.
\end{abstract}

Keywords: chub; squalius cephalus; quality properties; brine salting; dry salting.

Practical Application: Quality properties of salted chub during storage at $4 \pm 0.5^{\circ} \mathrm{C}$

\section{Introduction}

Salting is one of the oldest food preservation methods. Salting is a process where the common salt $(\mathrm{NaCl})$, sodium chloride, is used as a preservative that penetrates the tissue; hence slows the bacterial growth and deactivates the enzymes. Some of the factors involved in salting of fish which play important role are purity of salt, quantify of salt used, method of salting, and weather conditions, flavor of the product.

In Turkey fish is usually consumed fresh while a small amount is processed in different ways. One of these is salting. Dry salting, brine salting and mixed salting are commonly used methods in salting of fish. Salting of seafood is done with salt. The main purpose of salting is to separate water from the fish and replace it with salt. Thus, the water concertation in fish decreases. Chlorine and sodium ions are carried from brine to fish, and water dipoles are carried from fish to the environment. The rate during this process is high, and it slows during ripening. The determinant factor in this process is the concentration of salt. Moreover, the size and thickness of the fish, whether its skin and scales are removed or not, whether the fish is in the period of rigor mortis or not, the freshness of fish and purity degree of salt are other important factors (Merritt, 1988; Kolsarici \& Candoğan, 1997). In salting process, there are 2 stages salting and ripening. The ripening of salted fishes is a biochemical process. During this period, biochemical changes occur in the tissue of fish, and protein and fat enzymes break up which cause these changes (Voskresensky, 1965).

In Turkey, consumption of salted fish is not widespread; however the brined form of Cyprinids (Vimba vimba, Capoeta pestai, and Carassius carassius), anchovy (Engraulis encrasicolus) and sardine (Sardina pilchardus) does occur, and is being consumed with pleasure (Göğüş \& Kolsarıcı, 1992).

The aim of this study was to determine the effects of brine and dry salting methods on the nutritional composition of chub and the changes on microbial that arise during storage.

\section{Materials and methods}

\subsection{Material}

Fresh chub (Squalius cephalus Linnaeus, 1758) was used for salting. The samples that make up the material of this study were actively hunted from Atatürk Dam, Bozova Gülbiten Village coast with a net having mesh size of $18 \mathrm{~mm}, 50 \mathrm{~m}$ depth, $150 \mathrm{~m}$ from the shore. $10 \mathrm{~kg}$ chubs length varying from 15 to $19 \mathrm{~cm}$, weight varying from 51 to $52 \mathrm{~g}$ was used in the study. The samples were iced right away, and then transported to laboratory within a field type cooler. Afterwards the heads and fins of the fish were cut and their gills, scales and internal organs were removed and finally washed with water.

\subsection{Salting process}

The samples were divided into two groups, and dry salting method was applied to one of the groups and brine salting method to the other. The fish, on which both salting technologies were applied, were stored for 120 days at $4 \pm 0.5^{\circ} \mathrm{C}$. 


\subsection{Brine salting}

In the brine salting method, the cleaned fish were placed inside plastic jars of 5 liters, and brine was added until the fish was completely covered and brined in $20 \%$ salt solution, fish to salt solution ratio is 1:1. Medium sized dry and clean table salt purchased from the market was used in this process.

\subsection{Dry salting}

An amount of salt was put on the bottom of plastic jars of 5 liters. The fish were rubbed with dry salt and placed in the jars. The concentration of salt was adjusted to be $20 \%$ of the fish's weight (fish weight: salt weight [5:1]). In this method salt having the same properties in brine salting was used.

\subsection{Analysis}

For the first two months, analyses of these samples were performed once every 15 days, and then they were performed on a monthly basis after that $60^{\text {th }}, 90^{\text {th }}$ and $120^{\text {th }}$ days. During each analysis period, 5 fish were chosen randomly from each group among the samples stored in the refrigerator, and then their fillets were drained and homogenized prior to analyses excluding the microbial analyses.

\section{Proximate analysis}

To determine the crude protein amount in the fish samples the EN ISO16634-1 method was used (Müller, 2014), lipid amount was determined using ISO 1443:1973 method (International Organization for Standardization, 1973) moisture was determined using Ludorff \& Meyer (1973) method and crude ash content was determined using the burning method (Association of Official Analytical Chemists, 2000).

\section{Physicochemical analysis}

Samples of fish flesh $(10 \mathrm{~g})$ were homogenized in sterile blenders with $10 \mathrm{~mL}$ of distilled water. $\mathrm{pH}$ value was measured using (INOLAB pH 7310 brand) $\mathrm{pH}$ meter at $16 \pm 1^{\circ} \mathrm{C}$ (Association of Official Analytical Chemists, 2000). Salt amount was determined using the Mohr method and resisting the titration with $0.1 \mathrm{~N}$ $\mathrm{AgNO}_{3}$ accompanied by $\mathrm{K}_{2} \mathrm{CrO}_{4}$ indicator (Karl, 1994).

\section{Microbiological analysis}

Plate Count Agar (PCA, Merck, 1.05463) feedlot was used to get the total mesophilic aerobic bacteria count (TMBC) and total psychrophilic aerobic bacteria count (TPBC), $25 \mathrm{~g}$ sample was weighted using $225 \mathrm{ml}$ sterile peptone water which was mixed in the stomacher (Mayo, HG 400V, Italy) and made homogenous. A diluent of $10^{-1}$ was prepared in this manner, and other sub-dilutions were prepared from that dilution. $1 \mathrm{ml}$ was taken from the prepared dilutions, and 3 parallel inoculations were performed using the pour plate method. TMBC was left in incubation for 72 hours at $30 \pm 1{ }^{\circ} \mathrm{C}$ (International Organization for Standardization, 2003). And TPBC was incubated for 10 days at $7 \pm 1{ }^{\circ} \mathrm{C}$ (International Organization for Standardization, 2003). Tempo (Biomerieux TEMPO ${ }^{\oplus}$ TC, 80 006) (Biomerieux, 2011) device is used to determine total coliform count (TC) group bacteria in the sample groups.

The computer program Tempo preparation unit was used to record sample information and recent dilution rate using the device and through the window by pressing F8 key. The cards used for the analysis were read by the barcode reader. Bacteria number was given by the Tempo device as log cfu/g. Tempo yeasts-moulds is an automatic test done by the Tempo device and it counts yeast and mould in $72-76$ hours at $25^{\circ} \mathrm{C}$. The method used for analysis is the same that was used for coliform bacteria analysis, just the incubation was for 5 days at $20^{\circ} \mathrm{C}$ temperature (Biomerieux TEMPO ${ }^{\circledR}$ YM, 80 001) (Biomerieux, 2013).

\subsection{Statistical analysis}

Statistical analysis was performed using "SPSS 18.0 for Windows software". Difference in the means between the groups was analyzed using T test. Duncan's multiple range tests were applied in order to do multiple means comparison. Statistical significance was set at $\mathrm{p}<0.05$.

\section{Results and discussion}

The changes in the nutrient composition of chub used in the study was examined in the raw material and salted products in storage, and the results obtained from the research are given in Table 1 . When the crude protein values of dry and brine salting groups were compared, the crude protein rate of dry salting (DS) was higher than for brine salting (BS) method, and

Table 1. Proximate and physicochemical analysis of chub samples.

\begin{tabular}{|c|c|c|c|c|c|c|c|c|c|c|c|c|}
\hline \multirow{2}{*}{$\begin{array}{l}\text { Storage time } \\
\text { (day) }\end{array}$} & \multicolumn{2}{|c|}{ Crude Protein (\%) } & \multicolumn{2}{|c|}{ Lipid (\%) } & \multicolumn{2}{|c|}{ Moisture (\%) } & \multicolumn{2}{|c|}{ Crude Ash (\%) } & \multicolumn{2}{|c|}{$\mathrm{pH}$} & \multicolumn{2}{|c|}{ Salt (\%) } \\
\hline & DS & BS & DS & BS & DS & BS & DS & BS & DS & BS & DS & BS \\
\hline Raw material & $20 \pm 1^{\mathrm{abc}}$ & $20 \pm 1^{b}$ & $7 \pm 0^{\mathrm{a}}$ & $7 \pm 0^{c}$ & $75 \pm 1^{\mathrm{d}}$ & $75 \pm 1^{b c}$ & $2 \pm 0^{\mathrm{a}}$ & $2 \pm 0^{\mathrm{a}}$ & $7 \pm 0^{\mathrm{a}}$ & $7 \pm 0^{\mathrm{a}}$ & $0 \pm 0^{\mathrm{a}}$ & $0 \pm 0^{\mathrm{a}}$ \\
\hline 15 & $21 \pm 0^{\mathrm{bc}}$ & $15 \pm 6^{\mathrm{a}}$ & $6 \pm 0^{\mathrm{a}}$ & $7 \pm 1^{\mathrm{bc}}$ & $62 \pm 2^{c}$ & $77 \pm 2^{c \star}$ & $11 \pm 1^{\mathrm{b}}$ & $2 \pm 1^{b *}$ & $6 \pm 1^{\mathrm{a}}$ & $7 \pm 1^{\mathrm{a}}$ & $21 \pm 1^{\mathrm{d}}$ & $10 \pm 1^{c *}$ \\
\hline 45 & $22 \pm 2^{c}$ & $15 \pm 1^{\text {a* }}$ & $6 \pm 1^{a}$ & $4 \pm 1^{\mathrm{a}}$ & $59 \pm 2^{\mathrm{bc}}$ & $73 \pm 2^{\mathrm{ab} \star}$ & $13 \pm 1^{c}$ & $8 \pm 1^{\text {b* }}$ & $6 \pm 1^{\mathrm{a}}$ & $7 \pm 1^{a}$ & $13 \pm 2^{\mathrm{b}}$ & $7 \pm 1^{\mathrm{b} *}$ \\
\hline 60 & $19 \pm 1^{\mathrm{ab}}$ & $13 \pm 2^{a \star}$ & $7 \pm 2^{\mathrm{a}}$ & $5 \pm 1^{\mathrm{ab}}$ & $61 \pm 1^{c}$ & $78 \pm 2^{c \star}$ & $13 \pm 1^{\mathrm{cd}}$ & $4 \pm 1^{\mathrm{b}^{*}}$ & $6 \pm 1^{\mathrm{a}}$ & $7 \pm 1^{\mathrm{a}}$ & $15 \pm 1^{\mathrm{bc}}$ & $8 \pm 2^{\mathrm{b} *}$ \\
\hline
\end{tabular}

$\mathrm{n}=3$; (mean value \pm standard deviation), DS: Dry salted, BS: Brine salted, $\mathrm{P}<0.05$. ( ${ }^{*}$ ) shows statistical differences of “Two-tailed Independent T-test” between two different applications (DS or BS) of same parameters (crude protein, lipid, moisture, crude ash, $\mathrm{pH}$, and $\mathrm{NaCl}$ ) in same line. Different letters (a-d) in same column show statistical differences of "Duncan Multiply Range Test” among different storage times (0-120 days) for same application (DS or BS) and parameter (crude protein, lipid, moisture, crude ash, $\mathrm{pH}$, and NaCl). 
the difference between the groups was statistically significant $(\mathrm{P}<0.05)$. The reason for the protein rate being higher in dry salted samples compared to brine salted samples is water loss, and it may be due to increase of dry matter and protein. When the two groups are assessed internally, it was determined that there is a statistically significant relation between the protein value in $\mathrm{BS}$ group and the days, and in $\mathrm{DS}$ and the days $(\mathrm{P}<0.05)$. In a study performed by Bilgin et al. (2007) on salted products, the protein rate in dry salted Salmo trutta magrostigma species was lower than its brine samples. This may be due to difference in specie being used. In a study performed on salted pearl mullet Chalcalburnus tarichi, it was determined that the high rate of protein was in salted products when compared to fresh fish (Kılınççeker \& Küçüköner, 2003). Al-Asous \& Al-Harbı (2016) discovered that protein value of the salted bluespot mullet increased throughout the storing process. In a study done by Yapar (1999), he noted that the protein rate decreases the longer the product was in storage both in the brine and dry salting methods applied to O. mykiss, but the decrease was higher in the brine group. In another research similar to this study, a decrease in protein amount was determined by using different salting techniques that were applied to V. vimba tenella (Işıklı, 2000). Pourashouri et al. (2015) and Latifa et al. (2014) found that the protein was lower in salted fish when compared to when the fish was fresh. While it was determined that high salt concentration causes protein loss, however in this study high salt concentration doesn't cause protein loss in dry salting method only in in brine (Kolsarici \& Candoğan, 1997). The reason for this may be due to the fish species being used, the salt amount, difference of salting methods and storage period.

In our study, the lipid values were $7 \pm 0 \%$ and the raw material gradually decreased in both salting methods, and on the $120^{\text {th }}$ day, they had decreased to $5 \pm 1 \%$ in dry salted group and to $4 \pm 1 \%$ in brine salted group. According to the statistical assessment performed, it was determined that the difference between two groups when it comes to lipid values was significant $(\mathrm{P}<0.05)$. In dry salting method, the loss in lipid amount was less. There was no statistically significant found between the lipid values in BS group and the storage days, and same can be said of DS group and the days $(P>0.05)$. The results obtained in this study shown similarity with the results in Tömek \& Yapar (1990), Turan \& Erkoyuncu (1997), and Ürküt \& Yurdagel (1985). In a study performed by Bilgin et al. (2007) on salted products, the total lipid content was found to be $2.551 \pm 0.157 \%$ in fresh fish, and on the $180^{\text {th }}$ day of storage, this value decreased to $1.332 \pm 0.119 \%$ in dry salted samples and to $1.039 \pm 0.030 \%$ in brine salted samples. Our results are in agreement with the results from this research. That the reason for the decrease in the lipid content in salted products may depend on the draining and removal of fat from the fish's tissue and as result of compaction of tissue due to osmotic pressure and denaturation of protein caused by salt (Yapar, 1989). While the moisture rate was determined to be $75 \pm 1 \%$ in raw material, it increased to $77 \pm 2 \%$ in samples treated with brine salting in the first 15 days, however it decreased to $62 \pm 2 \%$ in samples treated with dry salting method. At the end of $120^{\text {th }}$ day, decrease in moisture rates was observed and recorded as $75 \pm 2 \%$ in brine salting group and $57 \pm 2 \%$ in the dry salting group. It was determined that the moisture loss in dry salting was higher compared to brine salting. According to the statistical assessment performed, it was determined that the difference between two groups with respect to moisture values was significant $(\mathrm{P}<0.05)$. While statistically significant relation was observed between the moisture value and the days in $\mathrm{BS}$ group $(\mathrm{P}<0.05)$, there was no such statistically significant between the $\%$ moisture value and the days in the group where dry salting was applied $(\mathrm{P}>0.05)$. Beyond this during the salting process, outrun of water occurs due to the penetration of the salt in the muscular tissues of the fish, and therefore dry matter rate increases while humidity rate decreases along with water outrun. An increase of $15.57 \%$ of dry matter in the sardine fish (S. pilchardus) stored for 10 months after being salted with $20 \%$ concentration of salt was observed. This means there was a decrease of moisture content (Ürküt \& Yurdagel, 1985). Some researchers (Turan \& Erkoyuncu 1997) have determined that the dry matter amount in O. mykiss and S. salar which were salted using different salting methods increased during storage period at $4{ }^{\circ} \mathrm{C}$ when compared to the initial values. The obtained results support our results.

According to statistical assessment performed for the two groups with respect to ash values, it was determined that the difference was significant $(\mathrm{P}<0.05)$. Ash amount was $2 \pm 0 \%$ in raw material, however there were increases and decreases during the storage period for both groups, and by the end of $200^{\text {th }}$ day, it reached $10 \pm 2 \%$ in samples treated with brine while it was $19 \pm 2 \%$ in samples treated with dry salting. Despite not being able to determine a statistically significant relation between the ash value and the days in $B S$ group $(P>0.05)$, it was determined that there was a statistically significant relation between the ash value and the days in DS group $(\mathrm{P}<0.05)$.

It is known that inorganic matter increases in salted fish and it depends on preservation period and salt rate. Inorganic matter and salt rates increase along the storage period in anchovy stored that had been salt cured and were in storage for 29 weeks, and that this condition affects other components (Kolsarici \& Candoğan, 1997). The obtained findings support our study.

The $\mathrm{pH}$ value is used as an indicator of degree of freshness or spoilage of a fish. In fresh fish pH is close to neutral, first it decreases due to lactic acid arising from death, however then it increases because of deterioration. The reason for this increase is the disruption to the oxidation-reduction balance along with the effect of enzymes and bacteria, and the changes in the concentration of free hydrogen and hydroxyl ions (Işıklı, 2000; Varlık et al., 1993). The increase in $\mathrm{pH}$ indicates the loss of quality (Latifa et al., 2014). In our study, the $\mathrm{pH}$ value started with $7 \pm 0$ in fresh fish and it was $6 \pm 0$ in the $120^{\text {th }}$ day in the fish treated with DS and $7 \pm 1$ for the fish treated with BS. Therefore it was observed that there is no regular increase or decrease in the $\mathrm{pH}$ measurements, and it was determined that there was a statistically significant relation between the $\mathrm{pH}$ values in $\mathrm{DS}$ and $\mathrm{BS}$ groups $(\mathrm{P}<0.05)$. It was also observed that there was no statistically significant relation between the $\mathrm{pH}$ value in $\mathrm{BS}$ group and days in storage, and same can be said for the DS group $(\mathrm{P}>0.05)$. In a study performed on a vimba vimba fish ( $V$. vimba tenella), it was determined that the $\mathrm{pH}$ value decreased to 6.85 from 6.99 on the $7^{\text {th }}$ day, and then increased 
to 7.37 for samples which used brine method, and that these values changed to 6.61 for (DS) and 6.71 for (BS) after being in storage for 118 days (Işıklı, 2000). Therefore it exhibited an irregular change during the preservation period. Another study performed using salted trout, showed that the $\mathrm{pH}$ value of the samples which were brine salted was higher when compared to dry salted samples (Bilgin et al., 2007), and this supports the results of our study.

In the research, according to statistical assessment made in respect to \% salt amounts recorded along the storage period, it was determined that there was a statistically significant relation between the salt values used in dry salted and brine salted groups $(\mathrm{P}<0.05)$. On other hand it was determined that there was no statistically significant relation between the salt values used in the group where the BS was applied and storage days $(\mathrm{P}>0.05)$, and that there was statistically significant relation in between the salt values of the group to which DS was applied and the days $(\mathrm{P}<0.05)$. The salt amount measured in raw material was $(0 \pm 0 \%)$ and to be $15 \pm 2 \%$ in the DS group and $9 \pm 1 \%$ in BS group by the 120th day in storage. The results are similar to the results found in Yapar (1989) study in which the salt rate was determined to be $15.74 \%$ in dry salted trout and $11.74 \%$ in brine salted trout. Turan \& Erkoyuncu (1997) have discovered that salt penetration in the fish depends on fat content of fish, and that the process is slower in fatty fish and that it is higher in dry salting compared to brine. Tömek \& Yapar (1990) revealed in their study on trout that there is an increase in salt penetration along with the increase in preservation period. The obtained results are in agreement with the results other researches have been able to obtain so far.

During the study, two types of salting methods were applied, and microbial changes were measured in chubs and a storage period was given all this date can be seen in Table 2 .

The total mesophilic aerobic bacteria count (TMBC), was determined to be $5 \pm 0 \log \mathrm{cfu} / \mathrm{g}$ in raw material and $7 \pm 0 \log$ $\mathrm{cfu} / \mathrm{g}$ in the DS group and $7 \pm 0 \log \mathrm{cfu} / \mathrm{g}$ in the BS group by the end of 120 days of storage. When it came to changes in viable bacteria number, a statistically significant relation was determined to exist between the DS and BS groups $(\mathrm{P}<0.05)$.
While a decrease in bacterial development was expected due to the effect of salt, what actually occurred is a significant increase was observed in the number of total viable bacteria and it depended on the ripening period. The reason for this bacterial increase could be that the bacteria adapted to the environment and the skin that was not removed became a microbial source during the process. Todorov (1975) research shows that the total number of bacteria increases along the ripening period. Küçüköner \& Akyüz (1992) found 7.5x10 $-7.5 \times 10^{6} \mathrm{cfu} / \mathrm{g}$, and Nino de Onshuus (1974) between $6.5 \times 10^{6}-1.67 \times 10^{8} \mathrm{cfu} / \mathrm{g}$. Patir et al. (2006) reported that the total mesophilic aerobic bacterial count in salted grey mullet (Chalcalburnus tarichii) stored at $4 \pm 1{ }^{\circ} \mathrm{C}$ ranged from 2.0 to $5.0 \log \mathrm{cfu} / \mathrm{g}$, with average $3.94 \mathrm{log} \mathrm{cfu} / \mathrm{g}$. Al-Asous \& Al-Harbı (2016) reported that the total mesophilic viable count in salted wild mullet (Valamugil seheli) ranged from 3.62 to $4.15 \mathrm{cfu} / \mathrm{g}$. The data determined in our study and the data determined in these studies shows agreement.

While total psycrophile bacteria count was determined to be $6 \pm 0 \log \mathrm{cfu} / \mathrm{g}$ in raw material, by the $120^{\text {th }}$ day in storage it was determined to be $6 \pm 0 \log \mathrm{cfu} / \mathrm{g}$ in the group treated with DS and as $7 \pm 0 \log \mathrm{cfu} / \mathrm{g}$ in the group treated with BS. The change of psycrophile bacteria that occurred had a statistically significant relation between the two groups $(\mathrm{P}<0.05)$ Al-Asous \& Al-Harb1 (2016) reported that the total psychotropic viable counts in salted fish stored in a refrigerator ranged from $3.43 \pm 0.34$ to $4.49 \pm 0.52 \log \mathrm{cfu} / \mathrm{g}$.

When it came to changes in yeast-mould count, it was determined that there was a statistically significant relation between raw material and DS and BS groups $(P<0.05)$. The yeast-mould numbers were $3 \pm 0 \mathrm{log} \mathrm{cfu} / \mathrm{g}$ in the fresh fish however it varied along the storage period, and by the end of $120^{\text {th }}$ day, the number was $3 \pm 0 \log \mathrm{cfu} / \mathrm{g}$ in DS group and as $3 \pm 0 \log \mathrm{cfu} / \mathrm{g}$ in BS group.

Depending on raw material and storage period, it was determined that there was no statistically significant relation between groups regarding coliform bacteria numbers in products to which salting was applied to $(\mathrm{P}>0.05)$. Coliform group bacteria was $2 \pm 0 \log \mathrm{cfu} / \mathrm{g}$ in raw material and it reached $5 \pm 0 \log \mathrm{cfu} / \mathrm{g}$ on the $15^{\text {th }}$ day in the group treated with dry salt, and below detectable level $(<10 \mathrm{cfu} / \mathrm{g})$ in both groups in the remaining

Table 2. The microbial flora of salted chub during storage at $4 \pm 0.5^{\circ} \mathrm{C}(\log \mathrm{cfu} / \mathrm{g})$.

\begin{tabular}{|c|c|c|c|c|c|c|c|c|}
\hline \multirow{3}{*}{ Storage time (day) } & \multicolumn{8}{|c|}{ According to the groups } \\
\hline & \multicolumn{2}{|c|}{ TMBC } & \multicolumn{2}{|c|}{ TPBC } & \multicolumn{2}{|c|}{ Yeasts-Moulds } & \multicolumn{2}{|c|}{ TC } \\
\hline & DS & BS & DS & BS & DS & BS & DS & BS \\
\hline Raw material & $5 \pm 0^{\mathrm{a}}$ & $5 \pm 0^{\mathrm{a}}$ & $6 \pm 0^{\mathrm{a}}$ & $6 \pm 0^{a}$ & $3 \pm 0^{\mathrm{e}}$ & $3 \pm 0^{\mathrm{a}}$ & $2 \pm 0^{b}$ & $2 \pm 0^{\mathrm{b}}$ \\
\hline 30 & $6 \pm 0^{\mathrm{d}}$ & $8 \pm 0^{\mathrm{d} *}$ & $7 \pm 0^{\mathrm{d}}$ & $8 \pm 0^{\text {e* }}$ & $<10^{\mathrm{a}}$ & $3 \pm 0^{\text {ax }}$ & $<10^{\mathrm{a}}$ & $<10^{\mathrm{a}}$ \\
\hline 45 & $6 \pm 0^{\mathrm{b}}$ & $8 \pm 0^{\text {e* }}$ & $6 \pm 0^{c}$ & $8 \pm 0^{\mathrm{f} *}$ & $2 \pm 0^{c}$ & $5 \pm 0^{c *}$ & $<10^{\mathrm{a}}$ & $<10^{\mathrm{a}}$ \\
\hline 120 & $7 \pm 0^{\mathrm{e}}$ & $7 \pm 0^{\mathrm{b}}$ & $6 \pm 0^{\mathrm{a}}$ & $7 \pm 0^{\mathrm{b} *}$ & $3 \pm 0^{\mathrm{d}}$ & $3 \pm 0^{\mathrm{a} *}$ & $<10^{\mathrm{a}}$ & $<10^{\mathrm{a}}$ \\
\hline
\end{tabular}

$\mathrm{n}=3$; (mean value \pm standard deviation) DS: Dry salted BS: Brine salted, $\mathrm{P}<0.05$. *shows statistical differences of "Two-tailed Independent T-test" between two different applications (DS and BS) of same parameters (TMBC, TPBC, YM and TC) in same line. Different letters (a-g) in same column show statistical differences of "Duncan Multiply Range Test" among different storage times (0-120 days) for same application (DS or BS) and parameter (TMBC, TPBC, YM and TC). 
days in storage. Todorov (1975) research shows that coliform was found on the surface of Atlantic mackerel however it could not be found in the fish. The reason for the difference between our research and ours is the fish species, salting techniques, and storage period and storage temperature.

\section{Conclusions}

According to the obtained results, the quality was lower in fish treated with brine salting method, and $\mathrm{pH}$ value and microbial values (TMBC, TPBC, Yeasts-Moulds) were higher when compared to dry salting. A way to fix this may be to use a salt solution with higher concentration in order to increase lasting period of brine products. In the light of the findings obtained in this study, it was concluded that Squalius cephalus is a species more suitable for dry salting method. But chub is a fish with high fat rate, and using a fish with a lower fat concentration would give better results in salting process.

\section{Acknowledgements}

This study is a summary of Arzu Binici's master thesis. The Scientific Research Projects Administration Unit of Munzur University supported this research.

\section{References}

Al-Asous, A. I., \& Al-Harb1, A. H. (2016). Microbiological and physicochemical quality of salted bluespot mullet (Valamugil seheli) stored at different temperature. Journal of Food Safety. http://dx.doi. org/10.1111/jfs.12291.

Association of Official Analytical Chemists - AOAC. (2000). Official methods of analysis of the Association of Official Analytical Chemists. 17th ed. Gaithersburg: AOAC.

Bilgin, Ş., Ertan, Ö. O., \& Günlü, A. (2007). The effects on chemical composition of Salmo trutta macrostigma Dumeril, 1858 of different salting techniques. Ege University Journal of Fisheries \& Aquatic Sciences, 24(3-4), 225-232.

Biomerieux. (2011). Biomerieux Tempo ${ }^{\circledast}$ TC, 80 006, Automated test for use with TEMPO, for the enumeration of total coliform following the BAM definition 22-27 hours in food products. Marcy-l'Etoile: Biomerieux.

Biomerieux. (2013). Biomerieux Tempo ${ }^{\oplus}$ YM, 80 001, Automated test for use with TEMPO, for the enumeration of yeasts, mold in 72-76 hours in food products. Marcy-l'Etoile: Biomerieux.

Göğüş, A. K., \& Kolsarıcı, N. (1992). Fisheries technology. Ankara: Ankara University.

International Organization for Standardization - ISO. (1973). ISO 1443:1973 - Meat and meat products -- Determination of total fat content. Geneva: ISO.

International Organization for Standardization - ISO. (2003). ISO 4833-1:2003 - Microbiology of the food chain - Horizontal method for the enumeration of microorganisms -- Part 1: Colony count at 30 degrees $C$ by the pour plate technique. Geneva: ISO.

Iş1kl1, B. (2000). The effect of different salting tecniques on the chemical and microbiological quality of salted zahre (Vimba vimba tenella Nordman, 1840) (Master's thesis). Institute of Science and Technology, Isparta.
Karl, H. (1994). Überlegungenzur berechnung der salz - und sauregehalte im fishgewebewasservon marinierten fischereierzeugnissen. Infn Fischw, 41(1), 47-59.

Kılınççeker, O., \& Küçüköner, E. (2003). Determination of some physical, chemical and biochemical changes on salted pearl mullet (Chalcalburnus tarichi). Yüzüncü Yil Üniversitesi Ziraat Fakültesi Tarim Bilimleri Dergisi, 13(1), 55-59.

Kolsarici, N., \& Candoğan, K. (1997, Apr 9-11). Intensive salt applied to cure the anchovy (Engraulis engrasicholus) chemical changes in fish. In Akdeniz Balıkçılık Kongresi (pp. 199-207). Rome: FAO.

Küçüköner, E., \& Akyüz, N. (1992). Microbiological, physical, chemical and sensory characteristics determination of the micronutrient pearl mullet fish prepared with different brine method of Van - Ercis region. Y.Y.Ü. Fen Bilimleri Enstitüsü Dergisi, 1(1), 39-50.

Latifa, G. A., Chakraborty, S. C., Begüm, M., Nahid, M. N., \& Farid, F. B. (2014). Nutritional quality analysis of bangladeshi fish species, $M$. tengra (Hamilton-Buchanan, 1822) preserved with different salt curing methods in laboratory condition. American Journal of Food and Nurition, 2(6), 100-107.

Ludorff, W., \& Meyer, V. (1973). Fish and fisher products. HamburgBerlin: Paul PareyVerlag.

Merritt, J. H. (1988). Refrigeration on fishing vessel. London: Shipowners' Club.

Müller, J. (2014). EN ISO16634-1 - Comparison and considerations for Nitrogen/Protein analysis of food and feed. Hillerod: FOSS.

Nino De Onshuus, Y. (1974). Studies an salted fish (Sbst. Only). Revista del Institudo de Investigaciones Technologicas, 16(91), 33-43.

Patır, B., Gürel İnanlı, A., Öksüztepe, G., \& İlhak, O. I. (2006). Microbiological and chemical qualities of salted grey mullet (Chalcalburnus tarichii Pallas, 1811). International Journal of Science \& Technology, 1(2), 91-98.

Pourashouri, P., Yeganeh, S., \& Shabanpour, B. (2015). Chemical and microbiological changes of salted caspian kutum (Rutilus frisii kutum) roe. Iranian Journal of Fisheries Sciences, 14(1), 176-187.

Todorov, L. (1975). Bacterial contamination of salted atlantic mackerel during processing (Abst. Only). Veterinarnomeditsinski. Nauiki, 12(2), 51-57.

Tömek, S. O., \& Yapar, A. (1990). The quality of the protective effect of certain additives in the production of salted trout, Ege Üniversitesi. Mühendislik Fakültesi Dergisi Gıda Mühendisliği Bölümü, 8(1), 59-68.

Turan, H., \& Erkoyuncu, İ. (1997, Apr 9-11). The effects on the quality and storage time of different salting methods in the various fish. In Akdeniz Balıkçılık Kongresi (pp. 191-197). İzmir: E.U. Faculty of Fisheries.

Ürküt, Y., \& Yurdagel, Z. (1985). Changes occurring in the nature of the salts is the sardine canning fish. Su Dergisi, 2(7-8), 77-90.

Varlık, C., Uğur, M., Gökoğlu, N., \& Gün, H. (1993). Quality control methods and principles in aquaculture (174 p., No. 17). Ankara: Ankara Üniversitesi Ziraat Fakültesi Gıda Böl.

Voskresensky, N. A. (1965). Salting of herring. In G. Borgstrom (Ed.), Fish as food (Vol. 3, Processing: Part I, pp. 107-129). New York: Academic Press.

Yapar, A. (1989). The investigation of some physical \& chemical changes in Trout applied different salting techniques (Master's thesis). Ege Unv. Institute of Science and Technology, İzmir.

Yapar, A. (1999). Quality changes in salted anchovy (Engraulis encrasicolus) produced using three different salt concentrations. Turkish Journal of Veterinary and Animal Sciences, 23, 441-445. 